\title{
RELIABILITY ANALYSIS AND PREDICTION FOR TIME TO FAILURE DISTRIBUTION OF AN AUTOMOBILE CRANKSHAFT
}

\section{ANALIZA NIEZAWODNOŚCI I PRZEWIDYWANIE ROZKŁADU CZASU DO USZKODZENIA WAŁU KORBOWEGO POJAZDU SAMOCHODOWEGO}

\begin{abstract}
This paper emphasizes on analysing and predicting the reliability of an automobile crankshaft by analysing the time to failure (TTF) through the parametric distribution function. The TTF was modelled to predict the likelihood of failure for crankshaft during its operational condition over a given time interval through the development of the stochastic algorithm. The developed stochastic algorithm has the capability to measure the parametric distribution function and validate the predict the reliability rate, mean time to failure and hazard rate. T, the algorithm has the capability to statistically validate the algorithm to obtain the optimal parametric model to represent the failure of the component against the actual time to failure data from the local automobile industry. Hence, the validated results showed that the three parameter Weibull distribution provided an accurate and efficient foundation in modelling the reliability rate when compared with the actual sampling data. The suggested parametric distribution function can be used to improve the design and the life cycle due to its capability in accelerating and decelerating the mechanism of failure based on time without adjusting the level of stress. Therefore, an understanding of the parametric distribution posed by the reliability and hazard rate onto the component can be used to improve the design and increase the life cycle based on the dependability of the component over a given period of time. The proposed reliability assessment through the developed stochastic algorithm provides an accurate, efficient, fast and cost effective reliability analysis in contrast to costly and lengthy experimental techniques.
\end{abstract}

Keywords: reliability; time to failure; monotonic function, hazard rate.

\begin{abstract}
W prezentowanej pracy przedstawiono metodę analizy oraz predykcji niezawodności wału korbowego pojazdu samochodowego oparta na analizie czasu do uszkodzenia (TTF) z wykorzystaniem funkcji rozkładu parametrycznego. W artykule, stworzono model TTF pozwalający na przewidywanie prawdopodobieństwa uszkodzenia wału korbowego w stanie pracy w danym przedziale czasu za pomoca nowo opracowanego algorytmu stochastycznego. Opracowany algorytm stochastyczny umożliwia mierzenie funkcji rozkładu parametrycznego oraz weryfikację przewidywanego wspótczynnika niezawodności, średniego czasu do uszkodzenia oraz wspótczynnika zagrożenia. Algorytm daje możliwość statystycznej weryfikacji modelu w odniesieniu do rzeczywistych danych dotyczacych czasu do uszkodzenia pochodzacych z lokalnego przemystu samochodowego. Weryfikacja taka pozwala na otrzymanie optymalnego modelu parametrycznego reprezentującego uszkodzenie części składowej. Zweryfikowane wyniki wykazały, że trójparametrowy rozkład Weibulla stanowi dokładne i wydajne narzędzie do modelowania wspótczynnika niezawodności w zestawieniu z rzeczywistymi danymi z próby. Proponowana dystrybuante parametryczna można wykorzystywać do doskonalenia konstrukcji oraz cyklu życia wału korbowego ponieważ daje ona możliwość przyspieszania i zwalniania mechanizmu uszkodzenia, na podstawie czasu, bez potrzeby regulacji poziomu naprężenia. Zatem, znajomość rozkładu parametrycznego oraz obliczonych na jego podstawie współczynników niezawodności i zagrożenia omawianego elementu mechanizmu korbowego, pozwala na doskonalenie konstrukcji oraz wydhużenie cyklu życia wału korbowego w oparciu o dane dotyczace jego niezawodności w danym okresie czasu. Proponowana metoda oceny niezawodności z wykorzystaniem opracowanego w artykule algorytmu stochastycznego umożliwia dokładna, wydajna, szybka i taniq analizę niezawodności w odróżnieniu od kosztownych i czasochłonnych technik eksperymentalnych.
\end{abstract}

Slowa kluczowe: niezawodność; czas do uszkodzenia; funkcja monotoniczna, wskaźnik zagrożenia.

\section{Introduction}

Failure of mechanical components such as the crankshaft is a constant key issue in managing the life cycle and risk analysis in the automobile industry. Generally, there are two methods used in determining the appropriate model in determining the time to failure for the automobile crankshaft which were (1). Understanding of the physical nature of failure through the experimental analysis, (2). By analysing and predicting the reliability based physical nature of failure through a stochastic process. It is known that the crankshaft is designed to last a lifetime with a significant safety limit [2-3,5] but its failure is still unavoidable due the variation of loading sequence during its operat- ing condition. Therefore, the consequences of failure of the crankshaft over its operating period would cause a more severe failure towards the engine block and the other connecting subcomponents $[6,22]$. It has been shown in the literature $[9-12,14,33]$ through their experimental analysis and simulation, the mean time to failure would be random due to high cycle and low stress of bending and torsion loads. Therefore, the component has to meet strict criteria, to ensure its reliability characteristics.

Nevertheless, there is a possibility of unavoidable component failure, which over time results from fluctuating service loading $[8,15]$. Not only does a component approaching fatigue failure threaten the correct functioning of the entire system, it causes other components to 
operate at suboptimal levels. Earlier experimental studies discussing the model of uncertainty have concluded that crack growth behaviour and the overall fatigue life are a result of variability and uncertainty in the load spectrum $[1,4,17]$. The importance of predicting fatigue failure is therefore unequivocal, and data from real-time monitoring can provide an accurate assessment of the durability of a component or structure, so performance can be maintained and the equipment lifetime is maximised [25-27]. Hence, stochastic modelling method will provide a new perspective in contrast to the conventional deterministic models. The prior model evolves in the direction of more computational mathematical methods based on the Markov process, rather than lengthier Karhunen-Loeve, Weiner integral, and Rayleigh techniques [23, 33-34].

Therefore, the modelling of the stochastic process using the suggested Markov chain provides an alternative method is assessing time to failure for a given structure or component. This is because the Markov chain is a probabilistic method that has the ability to synthetically generate and calculate an accurate relationship between experimental and simulation data based on the failure state conditions [10]. Likewise, the probability relates to the physical condition of components the reliability of random fatigue crack growth under variable amplitude loading can model the effects of the loading sequence and correlate this to the effects on the structure. Therefore, the failure of most components is relative towards the function performed by that component or the system over a given period of time where this was used to quantify the time to failure in terms of reliability $[35,36]$. This is because the Weibull distribution has the capability to increase or decrease the failure time without changing the level of stress through the various properties of the shape, scale and location parameter that was further characterized mathematically into 2 modes: (1). Non-monotonic failure - observing the bath tub curve, (2). Monotonic failure; in predicting the failure rate $[21,28]$.

The reliability lifecycle assessment of an automobile crankshaft is studied in this paper by modelling the stochastic algorithm based on the time to failure distribution.

This is much needed by the local automobile industry because at the present time, the automotive industry uses dynamic phenomena to predict fatigue failure under service loading that leads to conservative designs and higher costs in manufacture and maintenance. This stochastic algorithm modelling evolves around the mathematical tool to quantifying variable loading over a given period of time by synthetically generating time to failure data that is near similar based on actual max-min. This stochastic algorithm uses the probabilistic approach which consists of measures that define a sample space based on a time function, assigned to each outcome. Likewise, the importance of modelling the stochastic algorithm is to bridge the gap between the stochastic process and the experimental method by characterizing reliability lifecycle assessment through the parametric distribution models under random mixed mode loading. Thus, the stochastic algorithm is developed in order to assess the reliability rate, mean time to failure and hazard rate through the parametric distribution to model. More poignantly, the significant difference between the both the stochastic algorithm and experimental model is validated through the statistical process in determining the optimal reliability and hazard rate based on the parametric distributions.

\section{Methodology}

\subsection{Development of framework}

Reliability is an important tool in lifetime prediction for all mechanical components especially in the automobile industry. The reliability lifetime prediction for the crankshaft must be approached at the fundamental level by understanding the physics and mechanism of failure that would occurs on the crankshaft over a given period. Therefore it is important to identify the physics and mechanism of failure before beginning the reliability modelling (Fig. 1).

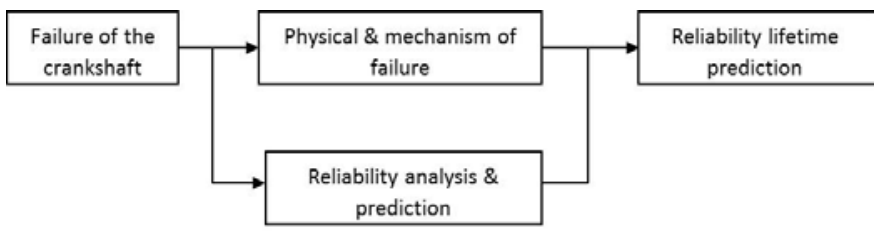

Fig. 1. Reliability lifetime prediction process flow for the crankshaft

The reliability time to failure assessment (Fig. 2) illustrates the operational loading condition of the crankshaft through a combination of the bending and torsional stresses, where in general the combination of the stresses will lead towards the failure of the crankshaft over a given period of time. Since the fatigue failure is considered to be stochastic in nature, therefore it is justified to model the failure of the component based on random loading over a given period of time. Various studies in the literature $[16,32]$ have mentioned that the time to failure for the component would be between 30 hours to 700 hours depending on the severity of the operating condition.

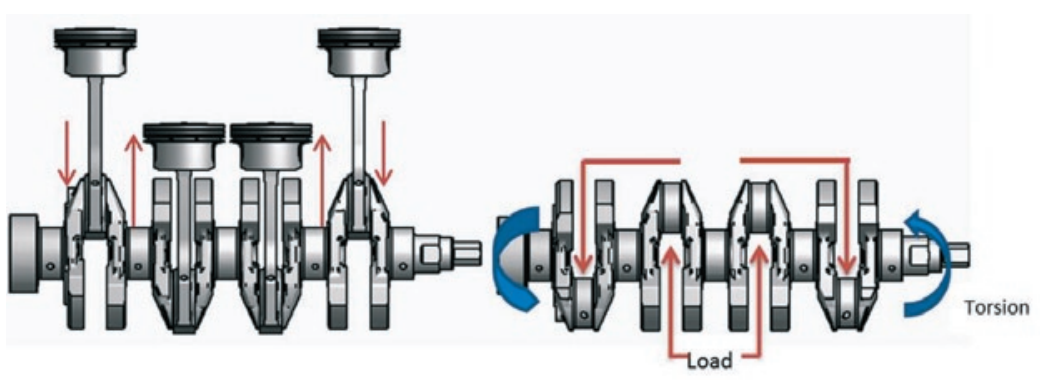

Fig. 2. Operational loading of the automobile crankshaft under bending and torsional stresses

Hence, the Discrete Markov Chain is used to computationally model the failure probability criterion through the characterization of failure states over a given period of time. Likewise, the development of the schematic stochastic algorithm provides a computational accurate and efficient prediction based on the time to failure $[7,13]$ when compared with the practical operating condition of the crankshaft. The development of the algorithm based on the framework provides the reliability assessment especially when there are constrains due to cost and lengthy duration of experimental setups. The TTF parametric distribution of Weibull, Lognormal and Gaussian is developed to determine the optimal model in reliability prediction for the crankshaft based on the physics and mechanism of failure (Fig. 3).

The flowchart (Fig. 3) explains:

1. Characterize the failure model of the crankshaft through the stochastic process based on the mechanism of failure.

2. Simulate the time to failure through the Markov Chain model to obtain near identical data as the sampling data.

3. Derive the TTF parametric distribution of Weibull, Lognormal and Gaussian distribution model to determine the reliability, failure rate and mean time to failure.

4. Statistically evaluate the reliability rate, failure rate and mean time to failure with obtained automobile sampling data.

5. Propose an appropriate TTF parametric distribution model as an optimal model in reliability analysis and prediction for the crankshaft.

In this paper, the TTF prediction and updating framework is presented in application to the problem of reliability assessment of the automobile crankshaft. This suggested method uses the Markov 


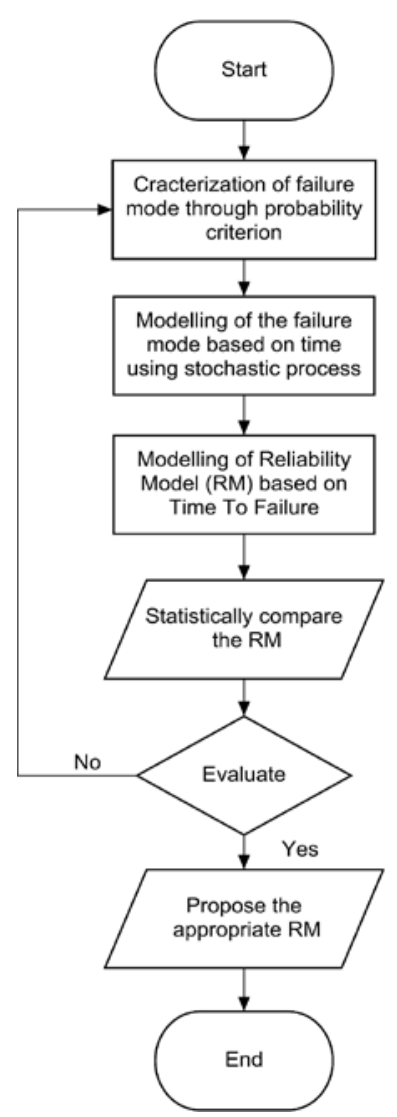

Fig. 3. Structure of the proposed TTF stochastic failure algorithm model.

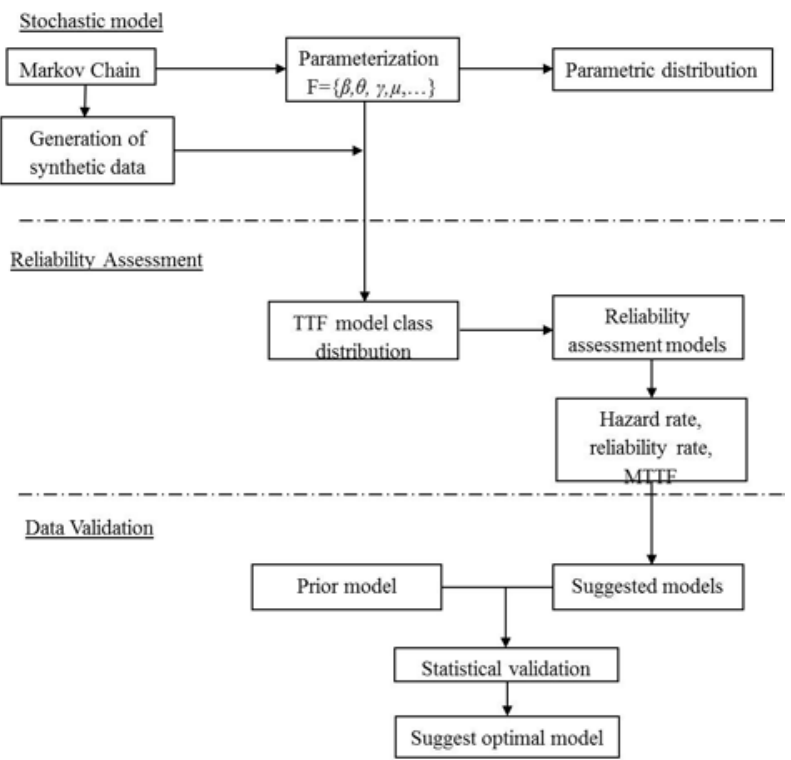

Fig. 4. Stochastic framework for TTF reliability assessment

\subsection{Modelling of time to failure through the Markov Chain model}

The characterization of failure is modelled as a state transition probability based on the mechanism of failure using the Markov Chain process. The Markov Chain has the capability in providing information for the future state, where the future state is independent of the past state given that present state is known [7]:

$P_{r}\left[X_{k}=j \mid X_{k-1}=i, X_{k-2}=i_{1}, \ldots, X_{0}=i_{k}\right]=P\left[X_{k}=j \mid X_{k-1}=i_{k}\right]=p_{i j}$
The time to failure for the crankshaft is modelled as a two state Markov Chain two-state condition (Fig. 5) based on the actual loading condition is represented in the state condition. Likewise consider the states as follows: B: bending and T: torsion where in the Markov model, each occurrence between states is characterized by an occurrence rate and is modeled as a recurrent state condition. The recurrent tells us that the chain will keep on changing over a given period of time until failure and it is observed that the transitions from $\mathrm{B}$ to $\mathrm{T}$ and $\mathrm{T}$ to $\mathrm{B}$ may have consequences but both form one unique cluster, i.e., the instrinct state of failure for the component.

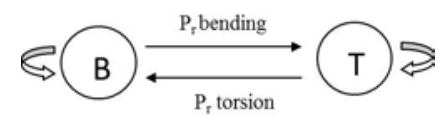

Fig. 5. Markov failure model (occurrence rate from state bending to torsion and vice versa).

Based on the experimental time to failure recorded from previous studies as mentioned earlier provided the physics and mechanism of failure for the crankshaft where from the preceding state condition (Fig. 4), the following Markov Chain model is numerically modelled to represent the state transition of failure over the given period of time.

$$
\begin{aligned}
& \mathrm{P}_{r}\left[X_{t}=B \mid X_{t-1}=T_{1}, X_{t-2}=T_{1}, \ldots, X_{0}=B_{t}\right] P\left[X_{t-1}=T_{1}, X_{t-2}=T_{2}, \ldots, X_{0}=B_{t}\right] \\
& =\mathrm{P}_{r}\left[X_{t}=B \mid X_{t-1}=T_{1}\right] P_{r}\left[X_{t-1}=T_{1}, X_{t-2}=T_{2}, \ldots, X_{0}=B_{t}\right] \\
& =\mathrm{P}_{r}\left[X_{t}=B \mid X_{t-1}=T_{1}\right] P_{r}\left[X_{t-1}=T_{1} \mid X_{t-2}=T_{2}, \ldots, X_{0}=T_{t}\right] P_{r}\left[X_{t-2}=T_{2}, \ldots, X_{0}=B_{t}\right] \\
& =\mathrm{P}_{r}\left[X_{t}=B \mid X_{t-1}=T_{1}\right] P_{r}\left[X_{t-1}=T_{1} \mid X_{t-2}=T_{2}\right] P_{r}\left[X_{t-2}=T_{2} \ldots, X_{0}=B_{0}\right] \\
& =\mathrm{P}_{r}\left[X_{t-1}=T \mid X_{0}=B\right]=P_{r}\left[X_{n+1}=T \mid X_{n}=B\right]
\end{aligned}
$$

where $X_{t}, t=0,1,2, \ldots$ The Markov Chain model from the preceding equations creates the ability to generate a new sequence of numerically random yet near similar sampling data that will be further used in determining the reliability of the crankshaft over a given period of time [24].

Hence, the developed Markov Chain model looks at the probabilistic criterion for bending and torsion loading based on the modelled state condition under the mixed mode loading criteria, even though it has been mentioned that the torsional load can be neglected because this load is considered less than ten percent of the bending load [Fonte]. Hence, based on the perception, probability matrix $\left(P^{n}\right)$ is modelled in terms of the probabilistic matrices to model the probabilistic condition though various sets of probabilistic condition to illustrate as the probability of going from $P_{B}$ to $P_{T}$.

$$
P^{n}=\left(\begin{array}{ll}
P_{11} & P_{12} \\
P_{21} & P_{22}
\end{array}\right)^{t}
$$

Due to this effect, the probability matrix $\left(P^{n}\right)$, in the form of the time $(T)$ was used to analyze the time condition each time the chain visited the individual state condition. Therefore, the stochastic process, in the form of the time vector, (T) was used to analyze the loading condition each time the chain visited the individual state condition:

$$
L=\left(\begin{array}{l}
L_{\max } \\
L_{\min }
\end{array}\right)
$$

Furthermore, the time taken for torsion loading to start its effect is when the crankshaft is in the operating condition due to forces acting in the direction of the axial rotation but it must be supported by the bending loading conditions and this is modelled in terms of the 
probability matrix $(\mu)$. The purpose of using this matrix is to provide a weightage on the failure criterion besides eliminating confusing for the initial condition of the failure of the component.

$$
\mu=\left(\begin{array}{ll}
\mu_{11} & \mu_{1 b}
\end{array}\right)
$$

Finally, the discrete Markov Chain is expressed in the generalized scalar terms, by providing a direct time-based approach for determining the TTF for the transition from one state to another. This generalized term is used in for the reliability assessment in in reliability assessment for the fatigue failure $[7,18]$.

$$
E(X)=\mu \cdot P^{n} \cdot[L]
$$

\subsection{Fundamental formulation for reliability}

TTF for an automobile crankshaft under loading condition would occur randomly over a given period of time $[29,30]$ and is modelled through the three parameter Weibull, Lognormal and Gaussian TTF parametric distribution function:

Weibull:

$$
f(t: \theta, \beta, \gamma)=\frac{\beta}{\theta}\left(\frac{t-\gamma}{\theta}\right) \exp \left[-\left(\frac{t-\gamma}{\theta}\right)^{\beta}\right]
$$

where $\theta=$ scale parameter, $\beta=$ shape parameter and $\gamma=$ location parameter.

Lognormal:

$$
f(t: \mu, \sigma)=\frac{1}{\sigma t \sqrt{2} \pi} \exp -\frac{1}{2} \frac{(\ln t-\mu)^{2}}{\sigma^{2}}
$$

Gaussian:

$$
f(t: \mu, \sigma)=\frac{1}{\sigma \sqrt{2} \pi} \exp -\frac{1}{2}\left(\frac{t-\mu}{\sigma}\right)^{2}
$$

where $\mu=$ mean, $\sigma=$ standard deviation.

The cumulative density function, reliability function and hazard rate function can be derived using (7), (8) and (9) for the TTF parametric distribution of Weibull, Lognormal and Gaussian.

Cumulative density function:

$$
F(t)=\int_{0}^{t} f(t) d t
$$

Reliability function:

$$
R(t)=1-F(t)
$$

Hazard rate function:

$$
\lambda(t)=\frac{f(t)}{R(t)}
$$

The failure rate distribution function for the TTF parametric distribution is derived based on its operating time:

Weibull:

$$
F(t: \beta, \theta, \gamma)=-\frac{1}{\left(\exp \frac{t-\gamma}{\theta}\right)^{\beta}}+1
$$

Lognormal:

$$
F(t: \mu, \sigma)=\frac{1}{2}\left[1+\operatorname{erf}\left[\frac{\ln (t)-\mu}{\sqrt{2} \sigma}\right]\right]
$$

Normal:

$$
F(t: \mu, \sigma)=\frac{1}{2}\left[1+\operatorname{erf}\left[\frac{x-\mu}{\sqrt{\left(2 \sigma^{2}\right)}}\right]\right]
$$

The TTF parametric distribution of Weibull, Lognormal and Gaussian is derived to determine reliability function of the crankshaft:

Weibull:

$$
R(t: \beta, \theta, \gamma)=\frac{1}{\left(\exp \frac{t-\gamma}{\theta}\right)^{\beta}}
$$

Lognormal:

$$
R(t: \mu, \sigma)=1-\operatorname{erf}\left[\frac{\ln (t)-\mu}{\sqrt{2} \sigma}\right]
$$

Normal:

$$
R(t: \mu, \sigma)=1-\operatorname{erf}\left[\frac{x-\mu}{\sqrt{\left(2 \sigma^{2}\right)}}\right]
$$

The behaviour of failure in terms of decreasing failure rate; constant failure rate; increasing failure rate hazard is obtained mathematically through (12) for the TTF parametric distribution of Weibull, Lognormal and Gaussian:

Weibull:

$$
\lambda(t: \beta, \theta, \gamma)=\left(\frac{\beta}{\theta}\right)\left(\frac{t-\gamma}{\theta}\right)^{\beta-1}
$$

Lognormal:

$$
\lambda(t: \mu, \sigma)=\frac{\frac{1}{2}\left[1+\operatorname{erf}\left[\frac{\ln (t)-\mu}{\sqrt{2} \sigma}\right]\right]}{1-\operatorname{erf}\left[\frac{\ln (t)-\mu}{\sqrt{2} \sigma}\right]}
$$

Normal:

$$
\lambda(t: \mu, \sigma)=\frac{\frac{1}{2}\left[1+\operatorname{erf}\left[\frac{x-\mu}{\sqrt{\left(2 \sigma^{2}\right)}}\right]\right]}{1-\operatorname{erf}\left[\frac{x-\mu}{\sqrt{\left(2 \sigma^{2}\right)}}\right]}
$$

Based on the failure rate distribution function, a statistical regression analysis is performed to determine the estimated values for shape and scale parameter

$$
F(t: \beta, \theta, \gamma)=1=\exp \left[-\left(\frac{t-\gamma}{\theta}\right)^{\beta}\right]
$$

using the Weibull transformation, the following is obtained:

$$
y=\beta(\ln (t)-\ln (\theta))
$$

where:

$$
x=\ln (t) \text { and } y=\ln \left[\frac{1}{\ln [1-F(t)]}\right]
$$

with the value of $\beta$ would represent the gradient of the slope and the intercepting axis is $\ln (\theta)$ and is used on WPP.

\section{Results and Discussion}

\subsection{Markov Chain simulation model}

The TTF was generated computationally and compared with the maximum and minimum of the expected time to failure as shown in Table 1. The first order discrete Markov Chain was convenient in modelling the sequence of maximum and minimum TTF for the extreme conditions based on the various RPM series. Hence, it is observed that the differences between the synthetically generated data using discrete Markov Chain and the automobile data were approximately between $2 \%$ to $9 \%$. It shows that the Markov Chain displayed properties of generating new but random sequence data for the sequences of maximum and minimum load conditions that were almost similar to the field data. Likewise, it is observed that the range of data gener- 
ated (Fig. 6) is within the given range limit of the failure time. This indicated that there will be no outliers in the TTF prediction of the component under the sequence of bending and torsional loads. Hence, making the reliability assessment a little less tedious because of the TTF falling with the specific control limit.

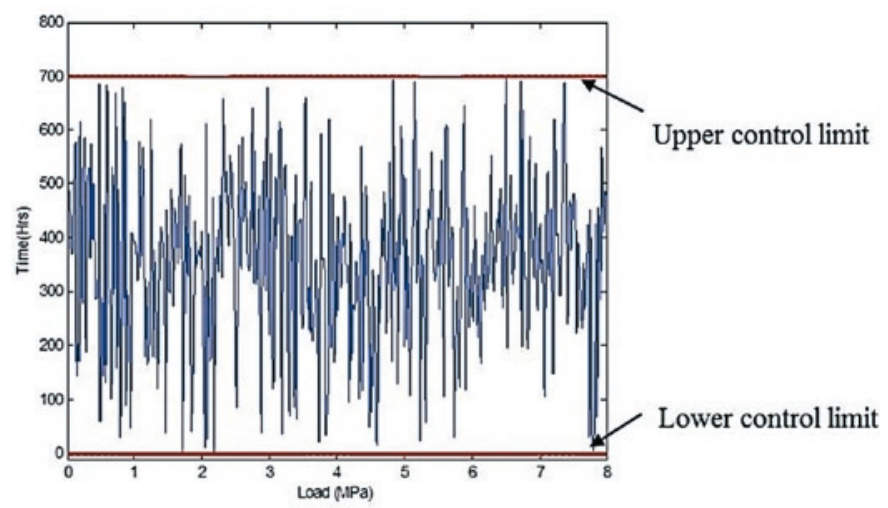

Fig. 6. Observation of the generated data within the upper and lower time limits.

Table 1. Synthetically generated data based on the actual min-max using Markov process

\begin{tabular}{|c|c|c||}
\hline \multirow{2}{*}{$\begin{array}{c}\text { Rotation per minute } \\
\text { (RPM) }\end{array}$} & \multicolumn{2}{|c|}{ Data generated from the Markov Chain } \\
\cline { 2 - 3 } & $\begin{array}{c}\text { Minimum } \\
\text { (Hours) }\end{array}$ & $\begin{array}{c}\text { Maximum } \\
\text { (Hours) }\end{array}$ \\
\hline 1000 & 0.12 & 699.43 \\
\hline 1500 & 0.09 & 697.38 \\
\hline 2000 & 0.065 & 698.38 \\
\hline 2500 & 0.068 & 695.25 \\
\hline 3000 & 0.057 & 699.17 \\
\hline 683500 & 0.098 & 697.12 \\
\hline 4000 & 0.067 & 696.02 \\
\hline 4500 & 0.013 & 693.29 \\
\hline 5000 & 0.05 & 695.87 \\
\hline 5500 & 0.028 & 699.58 \\
\hline 6000 & 0.041 & 685.82 \\
\hline 6500 & 0.021 & 694.63 \\
\hline
\end{tabular}

These sequences of maximum and minimum time are frequently used to model the failure rate and reliability using the parametric distribution through the parameterization properties such as the mean, standard deviation, shape and scale parameters. The effects of the parameterization properties is to accelerate and decelerate the failure of the component without adjust the stress levels of the component [29]. Therefore, this justifies the use of the of proposed algorithm in reliability assessment based on the characteristics of the various parametric distribution. Hence, the degree of error of the chosen model are evaluated individually to validate the accuracy of the synthetically generated data [10].

\subsection{Reliability analysis and prediction}

The shape parameter is evaluated on the WPP through the Weibull transformation of the numerical data set $\left(t_{1}, t_{2}, t_{3}, \ldots, t_{n}\right)$ generated from the Markov Chain to describe the properties for failure of the crankshaft during its lifetime (Fig. 7). This is an important aspect where the $W P P$ is used in estimating the probability of failure occurrence over a given period of time.
The shape parameter is evaluated to be greater than 2.0 with an estimated scale parameter of 220 hours. This indicates that the failure properties would gradually increase with minimal risk of early failure as shown in Table 2 with the understanding that the crankshaft is designed to withstand a lifetime.

The probability density function and cumulative density function provides a mathematical model for evaluating and predicting the failure of the crankshaft due to random bending and torsional stresses over a given period of time. TTF parametric distribution of Weibull, Lognormal and Gaussian is plotted (Fig. 8 and Fig. 9) to statistically determine the mean square error for each of the distribution with the sampling data obtained from the automobile industry. Although the Gaussian distribution is one of the most prominent distributions in statistics that is derived as the probability distribution of the sum of random variables but it is rarely used in modelling the failure distribution because it is defined within a range of the range $(-¥, ¥)$ though by the defined positive support. Likewise, the Gaussian distribution belongs to the exponential family, i.e. Weibull and lognormal distribution; that are the exponential family that is analytically tractable. Previous studies $[29,31]$ even suggested that in terms of reliability assessment, the Gaussian distribution can also be applied to representing failure time. However, in the automobile industry, the Gaussian distribution has never assumed to be normally distributed as the fail-

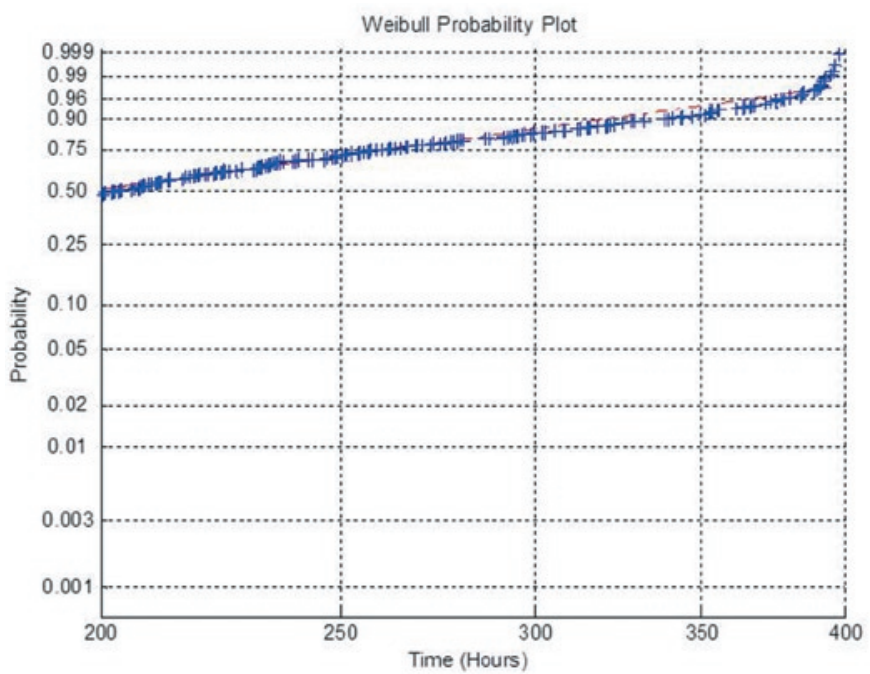

Fig. 7. Plot of three parameter Weibull for the crankshaft

Table 2. Theoretical properties of shape parameter

\begin{tabular}{||c|c|}
\hline \hline Shape Parameter & Properties \\
\hline $0<\beta<1$ & Decreasing failure rate \\
$\beta=1$ & Exponential distribution \\
$0<\beta<1$ & Increasing failure rate, concave \\
$\beta=1$ & Rayleigh distribution \\
$\beta>2$ & Increasing failure rate, convex \\
$3 \leq \beta \leq 4$ & Increasing failure rate, approaches normal \\
& distribution; symmetrical \\
\hline
\end{tabular}

ure would occur randomly under extreme loading condition [19-20]. Hence, by modelling the would provide an optimal model in determining the most appropriate parametric distribution to represent the TTF for the crankshaft under this operational condition.

In prediction of desired reliability life it is very important to understand the physics and failure mechanism of the crankshaft for better improvement. The contributing factor for failure mechanism of the crankshaft is due of the bending and torsional stresses with the fluctuation of loads during the operational time period [1, 2, 3, 5, 6, 32]. The optimal desired reliability life prediction (Fig. 10) based on the 


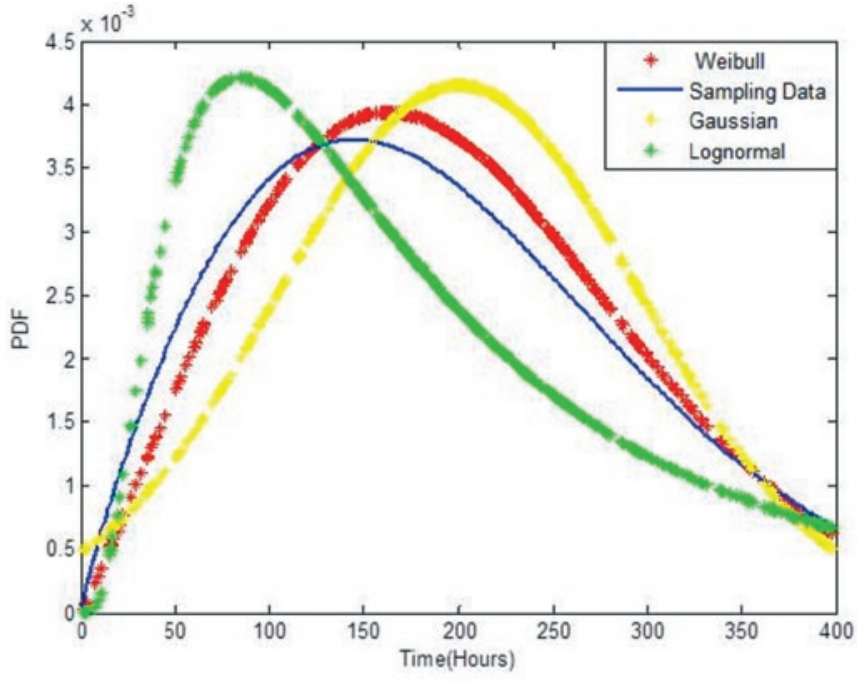

Fig. 8. Probability density function comparison between TTF parametric distribution and sampling data

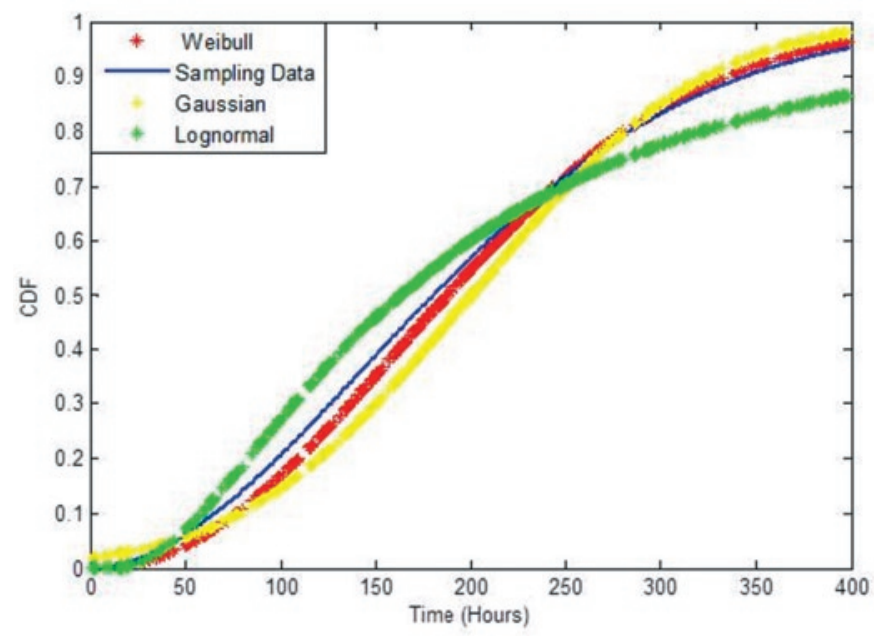

Fig. 9. Cumulative density function comparison between TTF parametric distribution and sampling data.

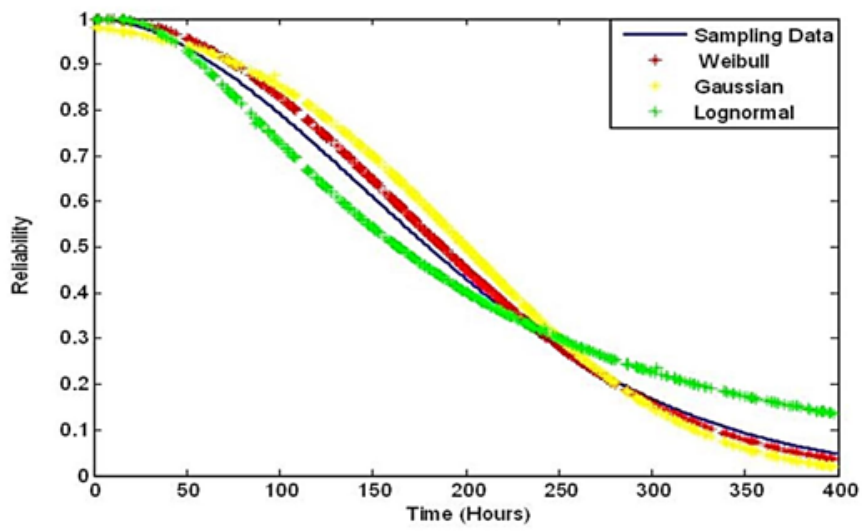

Fig. 10. Comparison of desired reliability life between TTF parametric distribution and sampling data

mechanism of failure using the Markov Chain process using on the TTF parametric distribution as derived earlier. It is shown that the desired reliability life will reduce gradually over time with a physical interpretation of gradual wear out and deterioration due bending and torsional stress acting onto the crankshaft over a given period of time.

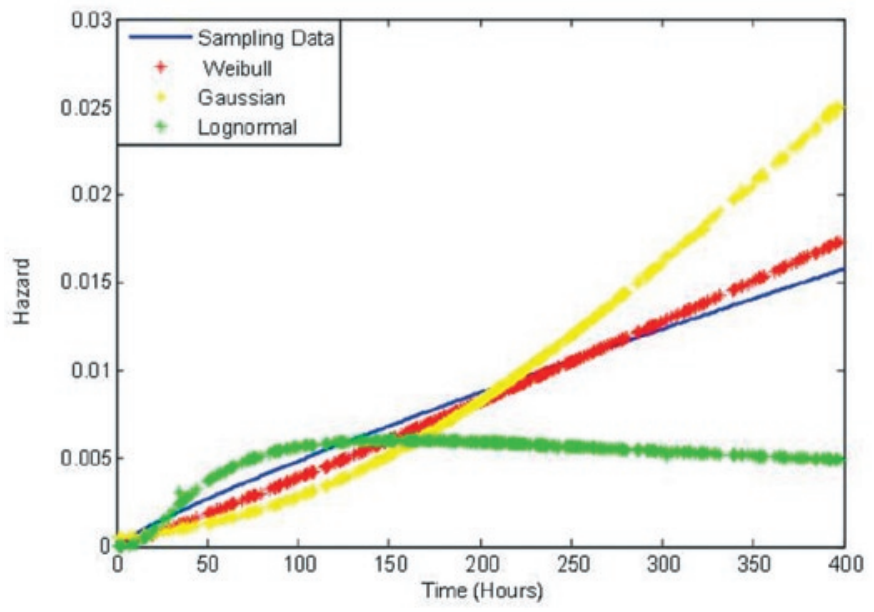

Fig. 11. Hazard rate comparison between TTF parametric distribution and sampling data

The failure rate (Fig. 11) displayed an exponential increment due to high cycle and low bending and torsional stress throughout the entire operational time period of the crankshaft. It was observed that Weibull showed minimal differences and near similarity towards the sampling data due to shape parameter, where shape parameter provides an important role in characterising the failure process model of the crankshaft under mixed mode loading when compared towards the automobile sampling data.

\subsection{Evaluation of TTF characterisation fitting for optimal reliability prediction}

Based from graphically comparison shown earlier, the accuracy of each distribution was tested using the statistical RMSE technique in determining the optimal model to represent the reliability for the crankshaft. Then the degree of error effect among the parametric data and the three statistical distributions is evaluated. Hence, among three kinds of statistical distributions, the Weibull three-parameter has best fitting effect with minimal percentage of error in comparison with the Gaussian and lognormal distribution as shown in Table 3. Therefore, three-parameter Weibull distribution is recommended for crankshaft TTF data fitting with the intension to verify and distinguish which TTF parametric distribution will provide as a fundamental predictive result in analysing and predicting the reliability for an automobile crankshaft based on the actual sampling data.

$$
R M S E=\sqrt{\frac{1}{n} \sum_{i=1}^{n}\left(\hat{Y}_{i}-Y_{i}\right)^{2}}
$$

In the preceding equation, $\hat{Y}_{i}$ is the sampling data obtained from the automobile industry and $Y_{i}$ is the numerical data set obtained from the Markov Chain model.

The statistical moment from numerical data set obtained from the Markov Chain model is compared towards the sampling data from the automobile industry as shown in Table 4 . It is observed that the MTTF for the three parameter Weibull occurs earlier compared to the sampling data indicating a better failure prediction compared to the other TTF distributions. The advantage of an earlier MTTF prediction is essential for preventive maintenance for burn-in period to increase the life cycle reliability and reduce the failure rate of the crankshaft. In practice, the MTTF is taken into account especially during the designing phase in order to avoid any over estimation of the safety factor. Besides that, the MTTF provides essential failure estimation that assist the development of the maintenance schedule. 
Table 3. RMSE comparison of three parameter Weibull, Gaussian and Lognormal functions towards the sampling data

\begin{tabular}{||l|c|c|c|c|c|c||}
\hline \multirow{2}{*}{ Distribution } & \multicolumn{2}{|c|}{ Three parameter Weibull } & \multicolumn{2}{c|}{ Gaussian } & \multicolumn{2}{c||}{ Lognormal } \\
\cline { 2 - 7 } & MSE & RMSE & MSE & RMSE & MSE & RMSE \\
\hline PDF & $7.03 \times 10^{-8}$ & 0.00027 & $3.30 \times 10^{-7}$ & 0.00057 & $8.96 \times 10^{-8}$ & 0.00029 \\
\hline CDF & 0.0062 & 0.079 & 0.0092 & 0.096 & 0.00917 & 0.096 \\
\hline Reliability function & 0.0043 & 0.065 & 0.0095 & 0.097 & 0.069 & 0.26 \\
\hline Hazard rate function & $6.16 \times 10^{-7}$ & 0.00079 & $6.01 \times 10^{-6}$ & 0.0025 & $7.53 \times 10^{-6}$ & 0.0027 \\
\hline
\end{tabular}

Table 4. Statistical moment comparison between sampling data and simulation.

\begin{tabular}{||l|c|c|c|c||}
\hline \multirow{2}{*}{\multicolumn{1}{|c|}{ Statistical Analysis }} & \multirow{2}{*}{ Sampling Data } & \multicolumn{3}{c||}{ Simulation } \\
\cline { 3 - 5 } & & Gaussian & Lognormal & Three parameter Weibull \\
\hline MTTF (Hours) & 200 & 201.2 & 225.3 & 199.1 \\
\hline Median (Hours) & 200 & 202.7 & 162.4 & 181.3 \\
\hline Standard Deviation (Hours) & 115.9 & 96.1 & 96.2 & 117.4 \\
\hline Variance (Hours) & 13443.5 & 9236.2 & 9246.9 & 13782.8 \\
\hline
\end{tabular}

\section{Conclusion}

This study investigated an optimal model to represent the TTF parametric distribution by developing the stochastic algorithm using the Markov Chain to predict the reliability of the crankshaft. The main purpose is to bridge the gap between the experimental and simulation analysis as throughout decades of investigation, numerous fatigue models have been proposed and a large amount of data has been derived from expensive experimental programs. The proposed algorithms models the fatigue failure under random TTF is to overcome the shortcomings of laboratory testing, because even under assumed ideal laboratory testing, fatigue tests showed a considerable amount of scatter under stochastic dynamic service loads. Hence, through the developed algorithm using the Markov process, the characterization of the parametric distribution functions had been modelled through the generation of synthetic data. Likewise, the statistical validation of the algorithm illustrated that the synthetically generated data from the Markovian process suggested that the three parameter Weibull distribution model provides an optimal reliability assessment with RMSE and MSE ranging 5 to $9 \%$ when compared towards the actual automobile sampling data.

Besides that, the physical failure properties is seen through the Weibull transformation method, where the shape parameter was the calculated to be greater than 2.0 to indicate that the failure of the crankshaft would occur gradually with low risk of early failure. Furthermore, the proposed algorithms showed that the three parameter Weibull distribution provides an optimal model in predicting the reliability, mean time to failure and hazard rate for an automobile crankshaft through the time dependent failure analysis. Thus, the three parameter Weibull distribution using the Markov Chain model of generating data is an accurate and efficient method for reliability lifecycle assessment when compare with the automobile sampling data in this case study.

\section{Acknowledgement}

The authors would like to thank the Ministry of Education for funding this study under the HLP Grant No. HLP-KPT.B.600-2/3781226085655 and also a token of appreciation to the National $A u$ tomobile Industry for providing the necessary information pertaining to the success of this study.

\section{References}

1. Aid A, Amrouche A, Bachir Bouiadjra B, Benguediab M, Mesmacque G. 2011. Fatigue life prediction under variable loading based on a new damage model. Materials and Design 2011; 23: 183-191, http://dx.doi.org/10.1016/j.matdes.2010.06.010.

2. Alfares M A, Falah A H, Elkholy A H. Failure analysis of a vehicle engine crankshaft. Journal of Failure Analysis and Prevention 2007; 7(1): 12-17, http://dx.doi.org/10.1007/s11668-006-9006-0.

3. Asi O. Failure analysis of a crankshaft made from ductile cast iron. Engineering Failure Analysis 2005; 13(8): 1260-1267, http://dx.doi. org/10.1016/j.engfailanal.2005.11.005.

4. Atzori B, Berto F, Lazzarin P \& Quaresimin M. A stress invariant based criterion to estimate fatigue damage under multiaxial loading. International Journal of Fatigue 2006; 28: 485-493, http://dx.doi.org/10.1016/j.ijfatigue.2005.05.010.

5. Bahumik S K, Rangaraju R, Venkataswamy M A, Baskaran T A, Parameswara M A. Fatigue fracture of crankshaft of an aircraft engine. Engineering Failure Analysis 2002; 9(3): 255-263, http://dx.doi.org/10.1016/S1350-6307(01)00022-X.

6. Becarra J A, Jimenez F J, Torrez M, Sanchez D T, Carvajal E. Failure analysis of reciprocating compressor crankshafts. Engineering Failure Analysis 2011; 18(2): 735-746, http://dx.doi.org/10.1016/j.engfailanal.2010.12.004.

7. Bocchini P, Saydam D, Franggopol D M. Efficient, accurate and simple Markov Chain Model for the life cycle analysis of bridge groups. Structural Safety 2013; 40: 51-64, http://dx.doi.org/10.1016/j.strusafe.2012.09.004.

8. Bue L F, Stefano A D, Giagonia C. Misfire detection system based on the measure of crankshaft angular velocity. Springer, 2007.

9. Changli C, Chengjie Z, Deping W. Analysis of an unusual crankshaft failure. Engineering Failure Analysis 2005; 12(3): 465-473, http:// dx.doi.org/10.1016/j.engfailanal.2004.01.006.

10. Chen X, Yu X, Hu R, Li J. Statistical distribution of crankshaft fatigue: Experiment and modelling. Engineering Failure Analysis 2014; 4: 210-220, http://dx.doi.org/10.1016/j.engfailanal.2014.04.015.

11. Chiachío M, Chiachío J, Rus G, Beck J L. Predicting fatigue damage in composites: A Bayesian framework. Structural Safety 2014; 51: 5768, http://dx.doi.org/10.1016/j.strusafe.2014.06.002.

12. Czarnigowski J, Drozdziel P, Kordos Paweł. Characteristic rotational speed ranges of a crankshaft during combustion engine operation at car maintenance. Eksploatacja i Niezawodnosc - Maintenance and Reliability 2002; 2(14): 55-62.

13. Distefano S, Peliafito A. Reliability and availability of dependent dynamic system with DRBD's. Reliability Engineering and System Safety 2009; 94(9): 1381-1393, http://dx.doi.org/10.1016/j.ress.2009.02.004. 
14. Drozdziel P, Krzywonos L. The estimation of the reliability of the first daily diesel engine start-up during its operation in the vehicle. Eksploatacja i Niezawodnosc - Maintenance and Reliability 2009; 1(41): 4-10.

15. Druschitz P A, Warrick R J, Grimley P R, Towalski R C, Killion D L, Marlow R. Influence of crankshaft materila and design on NVH characteristics of a Modern, Aluminum Block, V-6 Engine. SAE Technical Paper Series 1999-01-1225.

16. Fonte M, Li B, Reis L, Freitas M. Crankshaft failure analysis of a motor vehicle. Engineering Failure Analysis 2013; 35: 147-152, http:// dx.doi.org/10.1016/j.engfailanal.2013.01.016.

17. Gagg C R, Lewis, R P. In-service fatigue failure of engineered products and structures - Case study review. Engineering Failure Analysis 2009; 16: 1775-1793, http://dx.doi.org/10.1016/j.engfailanal.2008.08.008.

18. Gaver D P, Jacobs P A. Reliability growth by failure mode removal. Reliability Engineering and System Safety 2014;130: 27-32, http:// dx.doi.org/10.1016/j.ress.2014.04.012.

19. Jean M B, Cecile M. Damage tolerance and reliability assessment under random Markovian loads. Procedia IUTAM 2013; (6): 123-131.

20. Johannesson P. On rainflow cycles and the distribution of the number of interval crossings by a Markov chain, Probabilistic Engineering Mechanics 2002;17: 123-130, http://dx.doi.org/10.1016/S0266-8920(01)00033-9.

21. Jiang R, Murthy D N P. A study of Weibull Shape Parameter: Properties and Significance. Reliability Engineering and System Safety 2012; 96(12): 1619-1626, http://dx.doi.org/10.1016/j.ress.2011.09.003.

22. Jung D H, Kim H K, Pyoun Y S, Gafurov A, Choi G C, Ahn J M. Reliability prediction of the fatigue life of a crankshaft. Journal of Mechanical Science and Technology 2009; 23: 1071-1074, http://dx.doi.org/10.1007/s12206-009-0343-2.

23. Kihl D P, Sarkani S, Beach J E. Stochastic fatigue damage accumulation under broadband loadings. International Journal of Fatigue 1995; 17(5): 321-329, http://dx.doi.org/10.1016/0142-1123(95)00015-L.

24. Ling Y, Shantz C, Mahadevan S, Sankararaman S. Stochastic prediction of fatigue loading using real-time monitoring data International Journal of Fatigue 2011; 33(7): 868-879, http://dx.doi.org/10.1016/j.ijfatigue.2011.01.015.

25. Liu Y, Mahadevan S. Stochastic fatigue damage modeling under variable amplitude loading. International Journal of Fatigue 2007;29:11491161, http://dx.doi.org/10.1016/j.ijfatigue.2006.09.009.

26. Lu Z, Liu Y. Experimental investigation of random loading sequence effect on fatigue crack growth. Materials and Design 2011; 32: 47734785, http://dx.doi.org/10.1016/j.matdes.2011.06.034.

27. Nechval K N, Nechval N A, Berzins G, Purgailis M. Probabilistic assessment of the fatigue reliability. Eksploatacja i Niezawodnosc Maintenance and Reliability 2007; 3(35): 3-6.

28. Neetu S, Kanchan, J Suresh K S. The Beta Generalized Weibull distribution: Properties and application. Reliability Engineering and System Safety 2012; 102: 5-15, http://dx.doi.org/10.1016/j.ress.2012.02.003.

29. Newby M. Accelerated failure time models for reliability data analysis Reliability Engineering and System Safety 1988;20(3): 187-197, http://dx.doi.org/10.1016/0951-8320(88)90114-7.

30. Okamura H, Dohi T, Osaki S. Software reliability growth models with normal failure time distribution. Reliability Engineering and System Safety 2013; 116: 135-141, http://dx.doi.org/10.1016/j.ress.2012.02.002.

31. Pandey R K. Failure of diesel engine crankshaft Engineering Failure Analysis 2003; 10(2): 165-175, http://dx.doi.org/10.1016/S13506307(02)00053-5.

32. Ray A, Targilara S. A nonlinear stochastic model of fatigue crack dynamics. Probabilistic Engineering Mechanics 1997;12(1): 33-40, http:// dx.doi.org/10.1016/S0266-8920(96)00012-4.

33. Shen H, Lin J, Mu E. Probabilistic model on stochastic fatigue damage. International Journal of Fatigue 2000;22: 569-572, http://dx.doi. org/10.1016/S0142-1123(00)00030-X.

34. Sugier J, Anders G J. Modelling and evaluation of deterioration process with maintenance activities. Eksploatacja i Niezawodnosc Maintenance and Reliability 2013; 15(4): 305-311.

35. Xiuyun P, Zaizai Y. Estimation and application for a new extended Weibull distribution. Reliability Engineering and System Safety 2014; 121: 34-42, http://dx.doi.org/10.1016/j.ress.2013.07.007.

36. Zhang T, Dwight R. Choosing an optimal model for failure data analysis by graphical approach. Reliability Engineering and System Safety 2013; 115: 111-23, http://dx.doi.org/10.1016/j.ress.2013.02.004.

\author{
Salvinder Singh Karam SINGH \\ Shahrum ABDULLAH \\ Department of Mechanical and Material Engineering \\ Faculty of Engineering and Built Environment \\ Universiti Kebangsaan Malaysia \\ 43600 UKM \\ Bangi Selangor Malaysia
}

Nik Abdullah Nik MOHAMED

Department of Mechanical Engineering

Universiti Malaysia Pahang,

Pekan 26600 Pahang Malaysia

E-mail: salvinder@gmail.com, shahrum@eng.ukm.my, nikabdullah@ump.edu.my 